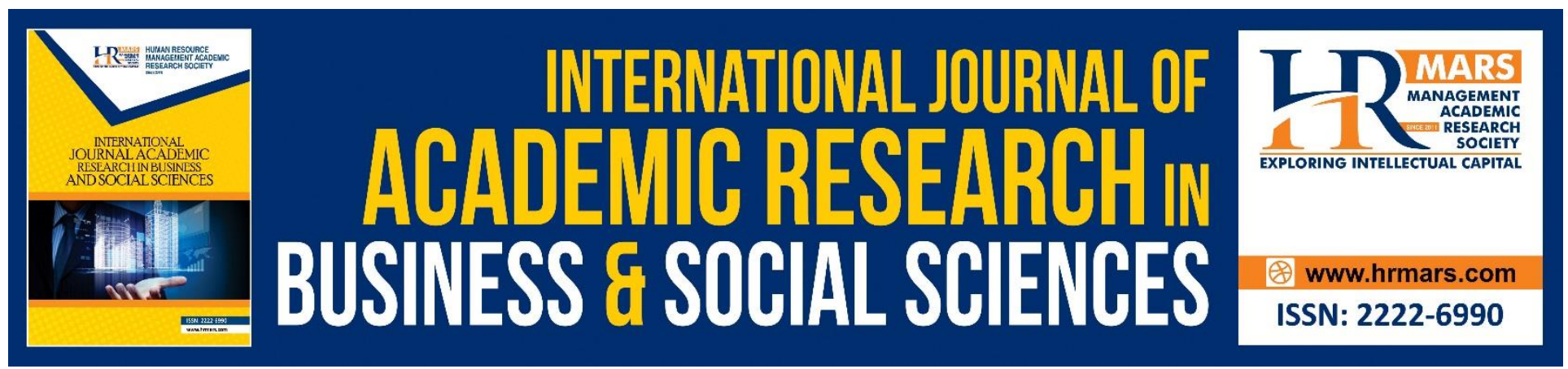

\title{
Conceptualizing Knowledge Management, Individual Absorptive Capacity and Innovation Capability: A Proposed Framework
}

\section{Anaqi Ahmad Saleh, Mad Khir Johari Abdullah Sani, Siti Arpah Noordin}

To Link this Article: http://dx.doi.org/10.6007/IJARBSS/v8-i9/4600

DOI: $\quad 10.6007 /$ IJARBSS/v8-i9/4600

Received: 02 August 2018, Revised: 25 August 2018, Accepted: 29 Sept 2018

Published Online: 15 October 2018

In-Text Citation: (Saleh, Sani, \& Noordin, 2018)

To Cite this Article: Saleh, A. A., Sani, M. K. J. A., \& Noordin, S. A. (2018). Conceptualizing Knowledge Management, Individual Absorptive Capacity and Innovation Capability: A Proposed Framework. International Journal of Academic Research in Business and Social Sciences, 8(9), 385-395.

\section{Copyright: (C) 2018 The Author(s)}

Published by Human Resource Management Academic Research Society (www.hrmars.com)

This article is published under the Creative Commons Attribution (CC BY 4.0) license. Anyone may reproduce, distribute, translate and create derivative works of this article (for both commercial and non-commercial purposes), subject to full attribution to the original publication and authors. The full terms of this license may be seen at: http://creativecommons.org/licences/by/4.0/legalcode

Vol. 8, No. 9, September 2018, Pg. 385 - 395

Full Terms \& Conditions of access and use can be found at http://hrmars.com/index.php/pages/detail/publication-ethics 


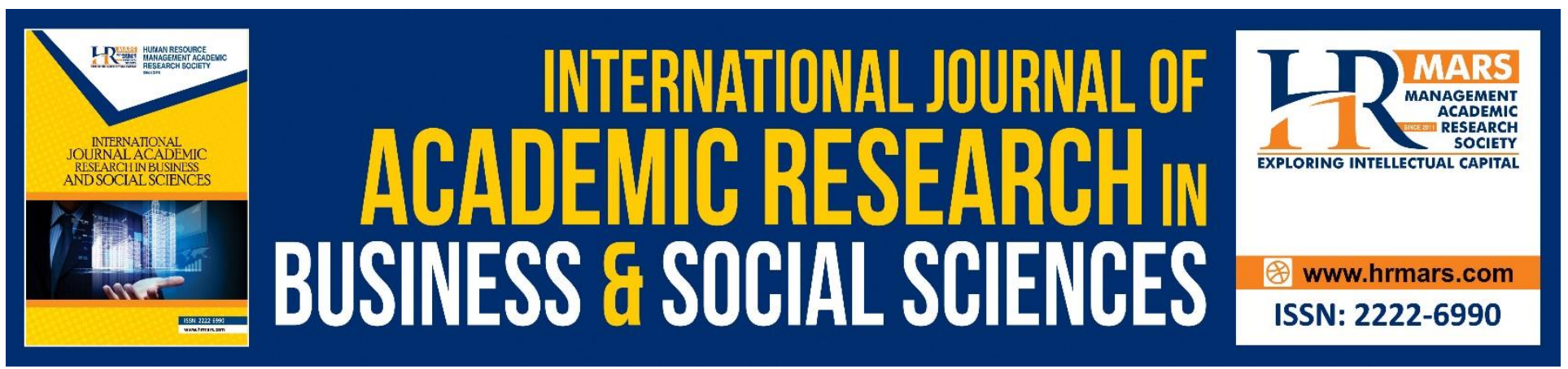

\title{
Conceptualizing Knowledge Management, Individual Absorptive Capacity and Innovation Capability: A Proposed Framework
}

\author{
Anaqi Ahmad Saleha, Mad Khir Johari Abdullah Sania, Siti Arpah \\ Noordina \\ ${ }^{\text {a}}$ Faculty of Information Management, Universiti Teknologi MARA, UiTM Selangor, 40150 Selangor, \\ Malaysia. Email: madkhirjohari@salam.uitm.edu.my
}

\begin{abstract}
The value of innovation as strategic resources in today's competitive environment is highly significant. Every organization and individual must have the ability to innovate in order to sustain in the market. This paper aims to explore existing knowledge in on the association between knowledge management, absorptive capacity and innovation capability particularly at an individual level. By examining relevant related literature, this paper presents a proposed theoretical framework that identifies antecedents of innovation capability from internal and external knowledge point of view. This paper calls for further empirical investigation on the proposed framework so that its relevancy can be inquired in different setting and context.
\end{abstract}

Keywords: Knowledge Management, Absorptive Capacity, Innovation Capability, Information Management

\section{Introduction}

Today's knowledge-based economy environment has increase knowledge value substantially. In brief, knowledge-based economy refers to any knowledge activities that intensify the scope of technical or scientific advancement in both product and services (Bano \& Taylor, 2015). With current revolutionary changes, competitive markets are no longer compete solely on land or financial capital, but also information and knowledge capabilities (Omotayo, 2015). Knowledge generated internally and embedded within organization's routines are crucial resources for learning new techniques, starting new initiatives, and maintain valuable lessons (Colakoglu, Yamao, \& Lepak, 2014). Thus, these tacit and explicit knowledge must be managed strategically (Hanson, 2014) starting with the ability to recognize their own strategic knowledge asset (Berri, 2014) and exploiting it in today's market environment.

Likewise, despite the fact that knowledge management concept derived from Knowledgebased View (KBV) theory focused on internal knowledge as main resource for organization's performance, Cohen \& Levinthal (1990) proposed absorptive capacity concept that are vital to increase the speed, magnitude and frequency of innovation through the process of acquiring, 
INTERNATIONAL JOURNAL OF ACADEMIC RESEARCH IN BUSINESS AND SOCIAL SCIENCES Vol. 8, No. 9, Sept. 2018, E-ISSN: 2222-6990 @ 2018 HRMARS

assimilating, exploiting and transforming the knowledge (Juknevičienè, Mikolaitytè, \& Šaparnienè, 2018). The ability to leverage external knowledge for organization's benefits is also one of the main features in innovation process on top of the ability to utilize existing internal knowledge (Belkahla \& Triki, 2011; Distel, 2017; Todorova \& Durisin, 2007; Wuryaningrat, 2013). This ability is now has attracted significant discussions, enquires and informed research on the link between external knowledge and firm performance (Ojo, Raman, Chong, \& Chong, 2014). By tapping into the external knowledge base, it benefits to widen the current knowledge pool so that will enable the organization's to explore and exploit new knowledge which eventually will produce profitable innovation (Enkel, Heil, Hengstler, \& Wirth, 2017)

Furthermore, the imperative contribution of innovation in organizations' competitive advantage regardless in technical or non-technical innovation is widely recognized (Ologbo \& Nor, 2015; Weerawardena \& Mavondo, 2011). Almost all sectors are highly dependent on their ability to innovate in order to success and sustaining their competitive advantage nowadays (Wuryaningrat, 2013). Even so, innovation process nowadays becomes more complex with the rapid changes of environment and highly competitive market. Tangible assets value alone is no longer sufficient to contend in todays landscape hence the need for steadfast resources like knowledge asset. Moos, Beimborn, Wagner, \& Weitzel (2013) postulates that the value of knowledge which consistently support to foster the innovation process consequently the need for efficient knowledge management in order the ensure the process (Delgado-Verde, Martín-de Castro, \& Emilio Navas-López, 2011). This ability to effectively manage the knowledge will help any organization in producing innovative commercial ends.

However, the discussion on the interrelationship between the knowledge management, absorptive capacity and innovation capability concepts are unfathomable due to unclear level of inquiry in understanding these notions. Although most of the theoretical and empirical development of the absorptive capacity concept and has occurred at the country, interorganizational, and organization level of analysis, these same propositions also operate at the individual level (Da Silva \& Davis, 2011; Roberts, Galluch, Dinger, \& Grover, 2012). Since innovation in firms starts with new ideas generated, adopted, or modified by individual employees (Roberts et al., 2012), an understanding of the antecedents of individual innovation capability is imperative (Kang \& Lee, 2017) to take advantage of external knowledge. Successful exploration and exploitation knowledge require high levels of absorptive capacity, which is found in individual motivation, action, and interaction (Volberda, Foss, \& Lyles, 2010). Nevertheless, innovative behavior primarily occurs at an individual level (Nonaka \& Takeuchi, 1995; Wang, Yang, \& Xue, 2017) since new and novel ideas generation is a reflection of existing human knowledge capabilities which in turn, will contribute to better innovation and influencing organization's performance (Rhee \& Choi, 2017). Lack of clarity surroundings this issue warrants further study in order to deepen the understanding to enhance the individual innovation capability which in turn will significantly serve innovation output of their organization.

Therefore, this paper aims to develop a proposed conceptual framework from relevant literature to identify predictors and result of absorptive capacity from individual unit of analysis and scope. The following section of this paper will analytically review individual absorptive capacity and innovation capability antecedent's literature to propose the framework in the third section. The remaining portion of the paper presents the conclusion with implication and future research directions. 
INTERNATIONAL JOURNAL OF ACADEMIC RESEARCH IN BUSINESS AND SOCIAL SCIENCES Vol. 8, No. 9, Sept. 2018, E-ISSN: 2222-6990 @ 2018 HRMARS

\section{Literature Review \\ Knowledge Management}

The debate on the exact definition of knowledge is an ongoing discourse started almost as early as human being existence. The definition of knowledge management is not as obscure as the definition of knowledge itself although most scholars accepts the accumulation of individual information, skills, capabilities, experiences and understandings in both coded and decoded form as simplified description of knowledge (Laudon \& Laudon, 2012; Rowley, 2007). In brief, knowledge management term refers to all activities related to handling knowledge from identification process by an individual up to organizational knowledge applications (Massingham, 2014; Ologbo \& Nor, 2015). This includes recognizing existing knowledge pool that resides in repository and in the individual minds which can be utilized for organization's benefits such as opportunity seeking, value enrichment, and others (Gonzalez \& Martins, 2017).

Although precise definition of knowledge management is currently undecided on account of the indistinct true concept of knowledge, several key categorizations of knowledge management definition can be made based on previous literature. Most of the study engaged knowledge management attributes to processes involved in managing knowledge. This first category was theoretically and empirically used to describe knowledge cycle process accumulate of knowledge creation, knowledge capture, knowledge retention, knowledge sharing, knowledge transfer, knowledge application and others (Alavi \& Leidner, 2001; Bhatt, 2001; Bizjak, 2006; Durst \& Runar Edvardsson, 2012; Gonzalez \& Martins, 2017) as the elaborate definition of knowledge management. Others extend the knowledge management conceptualization by not only process but also include the culture and technologies (Evans \& Easterby-Smith, 2001; Tsang, 1997). Another perspective defines knowledge management as any role in developing knowledge asset value of the organization and improving organizational capabilities at the same time (Gold, Malhotra, \& Segars, 2001)

The importance of knowledge management as competitive advantage tool is a consolidated fact. This knowledge management phenomenon has a strategic importance in developing unique capacities of organization and in providing it with sustainable competitive advantage (Masa'deh, Shannak, Maqableh, \& Tarhini, 2017). While both theoretical and practical side of knowledge management has undergone extensive discussion for about 20 years since 1990s, this field still considered as relatively immature (Alves, Gomes, Martins, \& Almeida, 2017; Tow, Venable, \& Dell, 2015). Although it has gained beyond trendy discussion that attracts high profile organizations from a government body to academic institutions interest, the tangible success of knowledge management is still arguable (Tow et al., 2015). Many organizations struggling to find right ways of implementing knowledge management that theoretically will enhance the competitive advantage but until now shows lack of satisfactory results. Unlike other resources, the underdeveloped model of knowledge management implementation is one of the main basis contributed to the unintended results (Ferraresi, Quandt, dos Santos, \& Frega, 2012).

\section{Absorptive Capacity}

From another standpoint, the ability to obtain and leverage external knowledge enhance the organization's competitive advantage. Findings on early studies on absorptive capacity, including the seminal work of Cohen \& Levinthal (1990) have placed a significant emphasis on the associations between absorptive capacity, innovation and performance of organizations with a greater focus placed on research and development (Saad, Kumar, \& Bradford, 2017). 
INTERNATIONAL JOURNAL OF ACADEMIC RESEARCH IN BUSINESS AND SOCIAL SCIENCES Vol. 8, No. 9, Sept. 2018, E-ISSN: 2222-6990 @ 2018 HRMARS

Kedia \& Bhagat (1988) first coined out the role of absorptive capacity in explaining firm receptiveness to foreign technology (Ojo et al., 2014). Later, Cohen \& Levinthal (1990) discussed the influential absorptive capacity concept that underpins most of the related field today. Cohen \& Levinthal established that the collective ability to leverage external knowledge to commercial ends termed as absorptive capacity. Zahra \& George (2002) further investigate the absorptive capacity idea by dividing the constructs into two main subsets namely potential and realized absorptive capacity. However, Todorova \& Durisin (2007) diverge the dimensions into complementary model contrasting sequential model by Zahra \& George (2002).

Nevertheless, countless researchers operated Zahra \& George (2002) and Todorova \& Durisin (2007) dimensions of absorptive capacity namely acquisition, assimilation, transformation and exploitation of knowledge to study this notion in organizational, team or individual settings. These four dimensions are believed to be complementary yet play different capabilities encompassing the ability to leverage external knowledge (Zahra \& George, 2002). Scholars also to some extent applying realized and potential absorptive capacity categorization introduces by Zahra \& George (2002) to enhance their understanding of this issue.

Although original discussions on absorptive capacity developed from organizational analysis level (Cohen \& Levinthal, 1990; Kang \& Lee, 2017; Zahra \& George, 2002), Ojo et al. (2014) argued that studies should also consider different specific level of absorptive capacity as every individuals in the organizations are had dissimilar capability to absorb external knowledge (Vinding, 2004). It has only recently begun the study on a micro foundation of absorptive capacity compared to organizational, unit or team since it's developed in early 1990s (Schweisfurth \& Raasch, 2018). Literature also revealed that absorptive capacity is multidimensional concept which applicable to a different level from bigger firms into individual capacity (Kang \& Lee, 2017; Schweisfurth \& Raasch, 2018). Thus, Kang \& Lee (2017) suggested the utilization of same sub-dimension of individual absorptive capacity as organizational level absorptive capacity since organizational wide knowledge capability determined by the individual within it.

\section{Innovation Capability}

Innovation happens only when the person and organization has the capability to innovate (Rajapathirana \& Hui, 2017). Innovation process nowadays acknowledged becoming more complex with the rapid changes of environment and highly competitive market. Tangible assets value alone is no longer sufficient to contend in today's landscape hence the need for steadfast resources like knowledge asset (Kumaraswamy \& Chitale, 2012). At this time, almost all sectors are highly dependent on their ability to innovate in order to success (Saunila, Ukko, \& Rantanen, 2012) and sustaining their competitive advantage (Wuryaningrat, 2013). Moos, Beimborn, Wagner, \& Weitzel (2013) postulates that the value of knowledge which consistently support to foster the innovation process consequently the need for efficient knowledge management in order the ensure the process (Delgado-Verde et al., 2011; Plessis, 2007). This capability to effectively manage the knowledge will significantly help any organization in producing innovative commercial ends (Darroch, 2005).

Altogether, the ability to produce innovations is the critical factor of successful operation in almost all industries (Migdadi, Zaid, Yousif, Almestarihi, \& Al-Hyari, 2017; Saunila et al., 2012; Yeşil, Büyükbeşe, \& Koska, 2013). With almost every competitors in market has slightly similar management capabilities like marketing, and human resources (Chang, Liao, \& Wu, 2017), the ability to continuously transformed and improved knowledge and ideas in products, services or processes will greatly contributes to organization success (Migdadi et al., 2017). It is no doubt that innovation 
INTERNATIONAL JOURNAL OF ACADEMIC RESEARCH IN BUSINESS AND SOCIAL SCIENCES

Vol. 8, No. 9, Sept. 2018, E-ISSN: 2222-6990 @ 2018 HRMARS

capability has been accepted as valuable asset in any industries (Rajapathirana \& Hui, 2017) and organizations with lower ability to innovate will gradually eliminated in the market.

\section{Proposed Framework Development}

To accomplish the objectives of this study, development of theoretical framework is required so that further conclusion can be made. Although there are endless debates on the precise dimensions of absorptive capacity theory, it was clear that number scholars applied Zahra \& George (2002) and Todorova \& Durisin (2007) dimensions of absorptive capacity. Knowledge acquisition, assimilation, exploitation, and transformation have been subjected to many studies to relate the main absorptive capacity theory with a competitive advantage. For example, Da Silva \& Davis (2011) adopted Zahra \& George (2002) construct of absorptive capacity to link creativity and innovation in academic settings. Also, Ojo et al. (2014) applied the four dimensions of absorptive capacity and suggest a specific level of each dimension. There are other studies used similar dimensions as well such as Delmas, Hoffmann, \& Kuss, (2011), Lowik et al. (2017), Wuryaningrat (2013), Xie, Zou, \& Qi (2018) and many more. Summarily, numerous studies that employed these four dimensions demonstrate its relevancy in this framework.

Provided that absorptive capacity is influenced by existing, prior and source of knowledge, connecting knowledge management to the antecedents of absorptive capacity are consistent with the initial concept's. Denoting definition of knowledge management with prior knowledge concept in absorptive capacity theory, recognizing existing knowledge asset is core pillar in knowledge management. According to Davenport \& Prusak (2000), knowledge management is "to identify, manage, and value items that the organization knows or could know" indicating pertinent role of knowledge identification. To some extent, this knowledge identification may include broad-spectrum knowledge about specific development in the field that is crucial for learning processes (Cohen \& Levinthal, 1990; Massingham, 2014a) and identifying future opportunities (Shepherd \& DeTienne, 2005). Thus, knowledge identification is first antecedents of absorptive capacity which conceal current knowledge resources before obtaining external knowledge.

On the other hand, apart from knowledge identifying process, Rowley (2000) proposed that knowledge access is one of the essential concepts in knowledge management. Knowledge access concerns on the ability of persons to attain required knowledge within the organization either in tacit or explicit form (Valentim, Lisboa, \& Franco, 2016). The ability to obtain current, precise and complete knowledge of the organization's environment will enhance their knowledge capability.

However, the existence of knowledge access does not necessarily indicate the efficient knowledge transfer practice because knowledge transfer only occurs at certain conditions (Inkpen \& Tsang, 2005) like trust and culture (Tsang, 1997). Thus, knowledge distribution is a significant aspect of knowledge management concepts. Knowledge distribution refers to the process by which information from different sources are shared (Gonzalez \& Martins, 2017) such as knowledge repository, subject matter expert, organizational memory and others. Adopting Rowley (2000) diversified concept of knowledge management, knowledge identification, knowledge access and knowledge distribution covered all other definitions of knowledge management from processes, value, and technological aspects.

Furthermore, innovation undoubtedly is the main pillar of competitive advantage. At an individual level, innovation is appropriately reflected by personal characteristics (Agarwal \& Prasad, 1998; Mun, Kirk, \& Jae, 2006) rather than innovation outcome or post-facto which could be time-consuming and partly biased (Hurt, Joseph, \& Cook, 1977). Innovativeness is an important determinant of 
INTERNATIONAL JOURNAL OF ACADEMIC RESEARCH IN BUSINESS AND SOCIAL SCIENCES Vol. 8, No. 9, Sept. 2018, E-ISSN: 2222-6990 @ 2018 HRMARS

organization's performance (Garcia \& Calantone, 2002) either in financial, operation or products aspects. Absorptive capacity original concepts also disclosed the distinctly pivotal role of innovation in advancing organization's competitive advantage. Hence, innovation capability is regarded as an outcome of individual absorptive capacity.

Therefore, based on previous discussion, proposed theoretical framework is as shown in following figure.

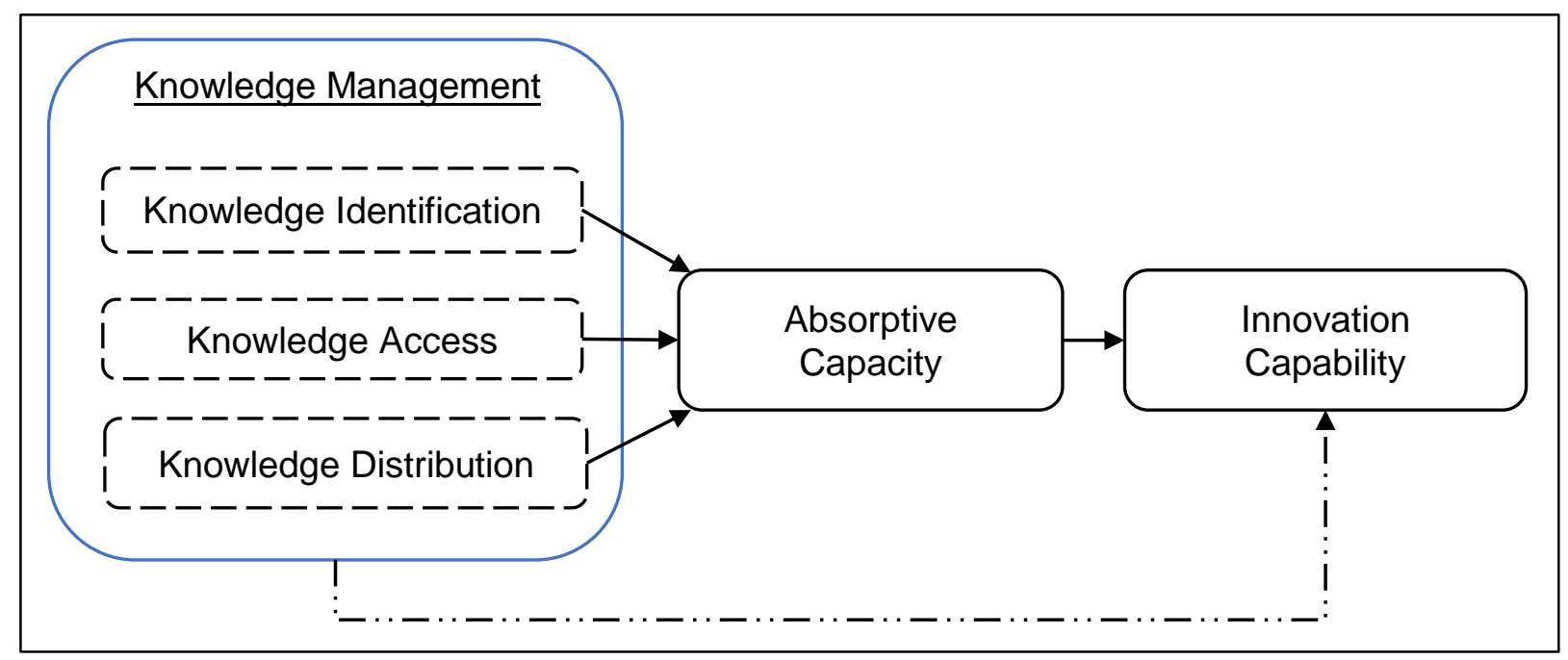

Proposed Theoretical Framework

\section{Conclusions}

This paper presents a proposed conceptual framework on the association of knowledge management, absorptive capacity and innovation capability. This paper concludes that knowledge management and absorptive capacity is imperative in individual innovation capability which in turn will affect their organization's success. Based on proposed framework, innovation capability can be improved through the strategic utilization of internal and external knowledge.

Innovation capability is vital for organizations' success and sustainability. This paper set out to contribute in body of knowledge domain by associating the interrelationship between knowledge management, absorptive capacity and innovation capability. It also presents the opportunity for further new area of investigations about the topics. However, the proposed framework is based on theoretical research and empirical studies are essential to examine the potential empirical applications of the framework. Further studies should focus validating the relevancy, and practicality of the proposed framework. Observing the framework in an empirical setting would provide significant insight to future researchers when employing the framework. Another area for future study is to identify appropriate dimension of individual innovation capability that influenced by absorptive capacity. Different context may require different innovation capability to achieve their objectives.

\section{References}

Agarwal, R., \& Prasad, J. (1998). A Conceptual and Operational Definition of Personal Innovativeness in the Domain of Information Technology. Information Systems Research, 9(2), 204-215. 
INTERNATIONAL JOURNAL OF ACADEMIC RESEARCH IN BUSINESS AND SOCIAL SCIENCES

Vol. 8, No. 9, Sept. 2018, E-ISSN: 2222-6990 @ 2018 HRMARS

https://doi.org/10.1287/isre.9.2.204

Alavi, M., \& Leidner, D. E. (2001). Knowledge Management and Knowledge Systems : Conceptual Foundations and Research Issue. MIS Quarterly, 25(1), 107-136. https://doi.org/10.2307/3250961

Alves, A. F., Gomes, C. M. A., Martins, A., \& Almeida, L. da S. (2017). Cognitive performance and academic achievement: How do family and school converge? European Journal of Education and Psychology, 4-11. https://doi.org/10.1016/j.ejeps.2017.07.001

Bano, S., \& Taylor, J. (2015). Universities and the knowledge-based economy: perceptions from a developing country. Higher Education Research and Development, 34(2), 242-255. https://doi.org/10.1080/07294360.2014.956696

Belkahla, W., \& Triki, A. (2011). Customer knowledge enabled innovation capability: proposing a measurement scale. Journal of Knowledge Management, 15(4), 648-674. https://doi.org/10.1108/13673271111152009

Berri, B. G. (2014). DBA Thesis. Exploring the Integration and Application of Knowledge in a Charitable Non-Government Organisation. University of Birmingham.

Bhatt, G. D. (2001). Knowledge management in organizations: examining the interaction between technologies, techniques, and people. Journal of Knowledge Management, 5(1), 68-75. https://doi.org/10.1108/13673270110384419

Bizjak, I. (2006). Principles and applications of knowledge management in the BC industry (with examples). Urbani Izziv, 17(1-2), 208-214. https://doi.org/10.5379/urbani-izziv-en-2006-17-0102-016

Chang, W.-J., Liao, S.-H., \& Wu, T.-T. (2017). Relationships among organizational culture, knowledge sharing, and innovation capability: a case of the automobile industry in Taiwan. Knowledge Management Research \& Practice, 15(3), 471-490. https://doi.org/10.1057/s41275-016-00426

Cohen, W. M., \& Levinthal, D. A. (1990). Absorptive Capacity: A New Perspective on Learning and Innovation. Administrative Science Quarterly, 35(1), 128-152. https://doi.org/10.2307/2393553

Colakoglu, S., Yamao, S., \& Lepak, D. P. (2014). Knowledge creation capability in MNC subsidiaries: Examining the roles of global and local knowledge inflows and subsidiary knowledge stocks. International Business Review, 23(1), 91-101. https://doi.org/10.1016/j.ibusrev.2013.08.009

Da Silva, N., \& Davis, A. R. (2011). Absorptive Capacity at the Individual Level: Linking Creativity to Innovation in Academia. The Review of Higher Education, 34(3), 355-379. https://doi.org/10.1353/rhe.2011.0007

Darroch, J. (2005). Knowledge management, innovation and firm performance. Journal of Knowledge Management, 9(3), 101-115. https://doi.org/10.1108/13673270510602809

Davenport, T. H., \& Prusak, L. (2000). Working knowledge - how organisations manage what they know. Boston, Massachusetts: Harvard Business School Press.

Delgado-Verde, M., Martín-de Castro, G., \& Emilio Navas-López, J. (2011). Organizational knowledge assets and innovation capability. Journal of Intellectual Capital, 12(1), 5-19. https://doi.org/10.1108/14691931111097890

Delmas, M., Hoffmann, V. H., \& Kuss, M. (2011). Under the Tip of the Iceberg: Absorptive Capacity, Environmental Strategy, and Competitive Advantage. Business \& Society (Vol. 50). https://doi.org/10.1177/0007650310394400

Distel, A. P. (2017). Unveiling the Microfoundations of Absorptive Capacity: A Study of Coleman's

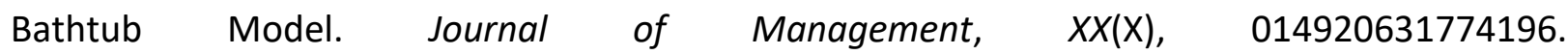


INTERNATIONAL JOURNAL OF ACADEMIC RESEARCH IN BUSINESS AND SOCIAL SCIENCES

Vol. 8, No. 9, Sept. 2018, E-ISSN: 2222-6990 @ 2018 HRMARS

https://doi.org/10.1177/0149206317741963

Durst, S., \& Runar Edvardsson, I. (2012). Knowledge management in SMEs: a literature review. Journal of Knowledge Management, 16(6), 879-903. https://doi.org/10.1108/13673271211276173

Enkel, E., Heil, S., Hengstler, M., \& Wirth, H. (2017). Exploratory and exploitative innovation: To what extent do the dimensions of individual level absorptive capacity contribute? Technovation, 6061(August 2016), 29-38. https://doi.org/10.1016/j.technovation.2016.08.002

Evans, N., \& Easterby-Smith, M. (2001). Three Types of Organizational Knowledge : Implications for the Tacit-Explicit and Knowledge Creation Debates. The Fourth International Conference for Organizational Learning and Knowledge Management, 1-23.

Ferraresi, A. A., Quandt, C. O., dos Santos, S. A., \& Frega, J. R. (2012). Knowledge management and strategic orientation: leveraging innovativeness and performance. Journal of Knowledge Management, 16(5), 688-701. https://doi.org/10.1108/13673271211262754

Garcia, R., \& Calantone, R. (2002). A critical look at technological innovation typology and innovativeness terminology: a literature review. Journal of Product Innovation Management, 19(2), 110-132. https://doi.org/10.1111/1540-5885.1920110

Gold, A. H., Malhotra, A., \& Segars, A. H. (2001). Knowledge management: An organizational capabilities perspective. Journal of Management Information Systems, 18(1), 185-214. https://doi.org/10.1080/07421222.2001.11045669

Gonzalez, R. V. D., \& Martins, M. F. (2017). Knowledge Management Process : a theoreticalconceptual research. Gestão \& Produção, 24(2), 248-265. https://doi.org/10.1590/0104530X0893-15

Hanson, K. (2014). Integrating Knowledge Management and E-Learning to Enhance Knowledge Creation and Conversion for Competitive Advantage in Small- and Medium-Sized Businesses. Retrieved from https://vpn.utm.my/docview/1553839774 ?accountid=41678

Hurt, H. T., Joseph, K., \& Cook, C. D. (1977). Scales for the measurement of innovativeness. Human Communication Research, 4(1), 58-65. https://doi.org/10.1111/j.1468-2958.1977.tb00597.x

Inkpen, A. C., \& Tsang, E. W. K. (2005). Social Capital, Networks, and Knowledge Transfer. Academy of Management Review, 30(1), 146-165. https://doi.org/10.5465/AMR.2005.15281445

Juknevičienè, V., Mikolaitytè, J., \& Šaparnienè, D. (2018). Assessing the Absorptive Capacity of Regional Innovation Systems: A Case Study of Lithuanian Regions. In J. Stejskal, P. Hajek, \& O. Hudec (Eds.), Knowledge Spillovers in Regional Innovation Systems: A Case Study of CEE Regions (pp. 49-79). Cham: Springer International Publishing. https://doi.org/10.1007/978-3-31967029-4_2

Kang, M., \& Lee, M. J. (2017). Absorptive capacity, knowledge sharing, and innovative behaviour of R\&D employees. Technology Analysis and Strategic Management, 29(2), 219-232. https://doi.org/10.1080/09537325.2016.1211265

Kedia, B. L., \& Bhagat, R. S. (1988). Cultural Constraints on Transfer of Technology Across Nations: Implications for Research in International and Comparative Management. Academy of Management Review, 13(4), 559-571. https://doi.org/10.5465/AMR.1988.4307424

Kumaraswamy, K. S. N., \& Chitale, C. M. (2012). Collaborative knowledge sharing strategy to enhance organizational learning. Journal of Management Development, 31(3), 308-322. https://doi.org/10.1108/02621711211208934

Laudon, K. C., \& Laudon, J. P. (2012). Management information systems: managing the digital firm (12th ed.). New Jersey: Prentice Hall.

Lowik, S., Kraaijenbrink, J., \& Groen, A. J. (2017). Antecedents and effects of individual absorptive 
INTERNATIONAL JOURNAL OF ACADEMIC RESEARCH IN BUSINESS AND SOCIAL SCIENCES

Vol. 8, No. 9, Sept. 2018, E-ISSN: 2222-6990 @ 2018 HRMARS

capacity: a micro-foundational perspective on open innovation. Journal of Knowledge Management, 21(6), 1319-1341. https://doi.org/10.1108/JKM-09-2016-0410

Masa'deh, R., Shannak, R., Maqableh, M., \& Tarhini, A. (2017). The impact of knowledge management on job performance in higher education. Journal of Enterprise Information Management, 30(2), 244-262. https://doi.org/10.1108/JEIM-09-2015-0087

Massingham, P. (2014). An evaluation of knowledge management tools: Part 1 - managing knowledge resources. Journal of Knowledge Management, 18(6), 1075-1100. https://doi.org/10.1108/JKM-11-2013-0449

Migdadi, M. M., Zaid, M. K. A., Yousif, M., Almestarihi, R., \& Al-Hyari, K. (2017). An Empirical Examination of Knowledge Management Processes and Market Orientation, Innovation Capability, and Organisational Performance: Insights from Jordan. Journal of Information \& Knowledge Management, 16(01), 1750002. https://doi.org/10.1142/S0219649217500022

Moos, B., Beimborn, D., Wagner, H.-T., \& Weitzel, T. (2013). The Role of Knowledge Management Systems for Innovation: An Absorptive Capacity Perspective. International Journal of Innovation Management, 17(05), 1350019. https://doi.org/10.1142/S1363919613500199

Mun, Y., Kirk, D., \& Jae, S. (2006). Understanding the Role of Individual Innovativeness in the Acceptance of IT-Based Innovations: Comparative Analyses of Models and Measures. Decision Sciences, 37(3), 393-426.

Nonaka, I., \& Takeuchi, H. (1995). The Knowledge-creating Company: How Japanese Companies Create the Dynamics of Innovation. New York: Oxford University Press.

Ojo, A. O., Raman, M., Chong, S. C., \& Chong, C. W. (2014). Individual antecedents of ACAP and implications of social context in joint engineering project teams: a conceptual model. Journal of Knowledge Management, 18(1), 177-193. https://doi.org/10.1108/JKM-08-2013-0332

Ologbo, A. C., \& Nor, K. M. (2015). Knowledge management processes and firm innovation capability: A theoretical model. Asian Social Science, 11(18), 10-17. https://doi.org/10.5539/ass.v11n18p10

Omotayo, F. O. (2015). Knowledge Management as an important tool in organisational management : A review of literature. Library Philosophy and Practice (e-Journal)., 1238, 1-23. Retrieved from http://digitalcommons.unl.edu/libphilprac/1238

Plessis, M. du. (2007). The role of knowledge management in innovation. Journal of Knowledge Management, 11(4), 20-29. https://doi.org/10.1108/13673270710762684

Rajapathirana, R. P. J., \& Hui, Y. (2017). Relationship between innovation capability, innovation type, and firm performance. Journal of Innovation \& Knowledge, 3(1), 1-16. https://doi.org/10.1016/j.jik.2017.06.002

Rhee, Y. W., \& Choi, J. N. (2017). Knowledge management behavior and individual creativity: Goal orientations as antecedents and in-group social status as moderating contingency. Journal of Organizational Behavior, 38(6), 813-832. https://doi.org/10.1002/job.2168

Roberts, N., Galluch, P. S., Dinger, M., \& Grover, V. (2012). Absorptive Capacity and Information Systems Research: Review, Synthesis, and Directions for Future Research. MIS Quarterly, 36(2), 625-648.

Rowley, J. (2000). Is higher education ready for knowledge management? International Journal of Educational Management, 14(7), 325-333. https://doi.org/10.1108/09513540010378978

Rowley, J. (2007). The wisdom hierarchy: Representations of the DIKW hierarchy. Journal of Information Science, 33(2), 163-180. https://doi.org/10.1177/0165551506070706

Saad, M., Kumar, V., \& Bradford, J. (2017). An investigation into the development of the absorptive 
INTERNATIONAL JOURNAL OF ACADEMIC RESEARCH IN BUSINESS AND SOCIAL SCIENCES

Vol. 8, No. 9, Sept. 2018, E-ISSN: 2222-6990 @ 2018 HRMARS

capacity of manufacturing SMEs. International Journal of Production Research, 7543(May), 116. https://doi.org/10.1080/00207543.2017.1327728

Saunila, M., Ukko, J., \& Rantanen, H. (2012). Innovation Capability and Its Measurement in Finnish SMEs. In Practice-Based Innovation: Insights, Applications and Policy Implications (pp. 417-435). Berlin, Heidelberg: Springer Berlin Heidelberg. https://doi.org/10.1007/978-3-642-21723-4_21

Schweisfurth, T. G., \& Raasch, C. (2018). Absorptive capacity for need knowledge: Antecedents and effects for employee innovativeness. Research Policy, (January). https://doi.org/10.1016/j.respol.2018.01.017

Shepherd, D. A., \& DeTienne, D. R. (2005). Prior knowledge, potential financial reward, and opportunity identification. Entrepreneurship: Theory and Practice, 29(1), 91-112. https://doi.org/10.1111/j.1540-6520.2005.00071.x

Todorova, G., \& Durisin, B. (2007). Absorptive Capacity: Valuing a Reconceptualization. Academy of Management Review, 32(3), 774-786. https://doi.org/10.5465/AMR.2007.25275513

Tow, W. N. H., Venable, J. R., \& Dell, P. (2015). Developing a Theory of Knowledge Identification Effectiveness in Knowledge Management. In PACIS 2015 Proceedings (p. 85). Association for Information Systems AIS Electronic Library (AISeL). Retrieved from http://aisel.aisnet.org/pacis2015/85

Tsang, E. W. K. (1997). Organizational learning and the learning organization: a dichotomy between descriptive and prescriptive research. Human Relations, 50(1), 73-89.

Valentim, L., Lisboa, J. V., \& Franco, M. (2016). Knowledge management practices and absorptive capacity in small and medium-sized enterprises: is there really a linkage? R\&D Management, 46(4), 711-725. https://doi.org/10.1111/radm.12108

Vinding, A. L. (2004). Human Resources; Absorptive Capacity and Innovative Performance. Research on Technological Innovation, Management and Policy, 8, 155-178. https://doi.org/10.1016/S0737-1071(04)08007-2

Volberda, H. W., Foss, N. J., \& Lyles, M. A. (2010). PERSPECTIVE-Absorbing the Concept of Absorptive Capacity: How to Realize Its Potential in the Organization Field. Organization Science, 21(4), 931951. https://doi.org/10.1287/orsc.1090.0503

Wang, J., Yang, J., \& Xue, Y. (2017). Subjective well-being, knowledge sharing and individual innovation behavior. Leadership \& Organization Development Journal, 38(8), 1110-1127. https://doi.org/10.1108/LODJ-10-2015-0235

Weerawardena, J., \& Mavondo, F. T. (2011). Capabilities, innovation and competitive advantage. Industrial Marketing Management, 40(8), 1220-1223. https://doi.org/10.1016/j.indmarman.2011.10.012

Wuryaningrat, N. F. (2013). Knowledge sharing, absorptive capacity and innovation capabilities: An empirical study on small and medium enterprises in North Sulawesi, Indonesia. Gadjah Mada International Journal of Business, 15(1), 61-78. https://doi.org/10.22146/gamaijb.5402

Xie, X., Zou, H., \& Qi, G. (2018). Knowledge absorptive capacity and innovation performance in hightech companies: A multi-mediating analysis. Journal of Business Research, (June 2017), 0-1. https://doi.org/10.1016/j.jbusres.2018.01.019

Yeşil, S., Büyükbeşe, T., \& Koska, A. (2013). Exploring the Link Between Knowledge Sharing Enablers, Innovation Capability and Innovation Performance. International Journal of Innovation Management, 17(04), 1350018. https://doi.org/10.1142/S1363919613500187

Zahra, S. A., \& George, G. (2002). Absorptive capacity: A review, reconceptualization, and extension. Academy of Management Review, 27(2), 185-203. https://doi.org/10.5465/AMR.2002.6587995 